\title{
Spatial genetic structure of the endemic alpine plant Salix serpillifolia: genetic swamping on nunataks due to secondary colonization?
}

\author{
Piotr Kosiński ${ }^{1,2}$ (D) Katarzyna Sękiewicz ${ }^{1}$ (1) $\cdot$ Łukasz Walas $^{1} \cdot$ Adam Boratyński $^{1} \cdot$ Monika Dering $^{1,3}$ (1)
}

Received: 11 February 2019 / Accepted: 26 July 2019 / Published online: 8 August 2019

(c) The Author(s) 2019

\begin{abstract}
Pleistocene climatic changes affected the current distribution and genetic structure of alpine plants. Some refugial areas for the high elevation species have been proposed in the Alps, but whether they could survive on nunataks, is still controversial. Here, the spatial genetic structure in Salix serpillifolia revealed by chloroplast (cpSSR) and nuclear (nSSR) microsatellites was compared with the MaxEnt-modelled geographic distributions under current and past (Last Glacial Maximum) climate conditions. Our results suggest that the genetic pattern of differentiation detected in S. serpillifolia may be explained by the existence of Pleistocene refugia, including nunataks. The geographical patterns of variation obtained from the chloroplast and nuclear markers were not fully congruent. The spatial genetic structure that was based on nSSRs was more homogenous, while the cpSSR-based pattern pointed at strong genetic structure along the Alps. Five populations from the Central Alps had a combination of local and unique cpSSR clusters and admixture of those occurring in the Western and Eastern Alps. These findings may indicate the local survival of small populations of $S$. serpillifolia that were subsequently populated by new colonists in the postglacial period.
\end{abstract}

Keywords High-mountain plants $\cdot \operatorname{cpSSR} \cdot \mathrm{nSSR} \cdot$ Genetic diversity $\cdot$ Differentiation $\cdot$ Alpine refugia

\section{Introduction}

Quaternary climate oscillations have caused entire plant zones to shift (Huntley and Birks 1983; Comes and Kadereit 1998; Tzedakis et al. 2013). The geographical ranges of many species have expanded and contracted in accordance with the climatic changes (Bennett et al. 1991; Hewitt 2004). The glaciated areas covered the lowlands of northern and central Europe and the high mountain ranges in the south, mainly the Alps and the Pyrenees, as well as part of the

Electronic supplementary material The online version of this article (https://doi.org/10.1007/s00035-019-00224-4) contains supplementary material, which is available to authorized users.

Piotr Kosiński

kosinski@up.poznan.pl

1 Laboratory of Systematics and Geography, Institute of Dendrology, Polish Academy of Sciences, Parkowa 5, 62-035 Kórnik, Poland

2 Department of Botany, Poznań University of Life Sciences, Wojska Polskiego 71c, 60-625 Poznań, Poland

3 Department of Forest Silviculture, Poznań University of Life Sciences, Wojska Polskiego 69, 60-625 Poznań, Poland
Carpathians (Ehlers and Gibbard 2004; Birks 2008). Contrary to what is expected, conditions during the last glaciation in Europe might not have given the high-mountain, alpine-adapted species, which are cold tolerant but strictly habitat-limited, the opportunity to enlarge their ranges (Stewart et al. 2010). Cooling might have increased the area that was available to some species and allowed them to expand. This is probably the case with some tundra plants, which had a larger range in the periglacial tundra than in the present period (e.g. Skrede et al. 2006). The relatively mild climate in the lowlands south of the Alps during the glacial periods allowed tree species to grow and persist but these conditions were likely not suitable for alpine species (Ravazzi 2002; Schönswetter et al. 2005; Stewart et al. 2010). Extensive areas to the north and east of the Alps also were likely not habitable for many high elevation plants because of the steppe vegetation that prevailed there under the cold and dry climate during the glacial period (Grichuk 1992; Schönswetter et al. 2005). Along with the expansion of the glaciers in the cold Quaternary phases, the habitats of the European high-mountain plants were becoming increasingly limited. Consequently, another type of glacial refugia 
Fig. 1 Sampled populations of Salix serpillifolia (black dots) and refugial areas in the Alps, as defined by Schönswetter et al. (2005): I-IV: southernAlpine (brown areas), V-VII: northern-Alpine (blue areas), VIII-IX: central alpine (purple areas); red asterisks: sites with macrofossils of Salix retusa agg

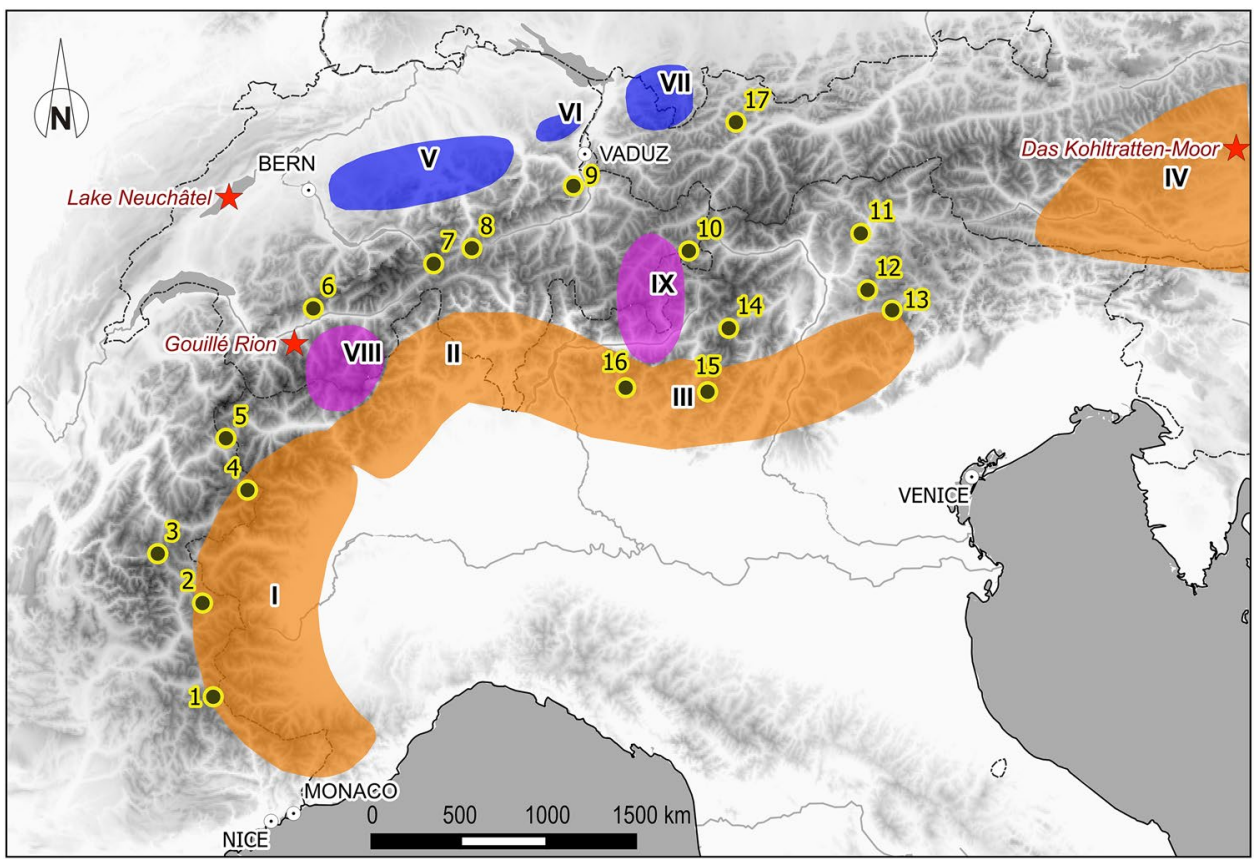

must have existed to support their survival during these periods.

In the period preceding the wide use of molecular markers, our knowledge regarding the refugia that could host alpine species was largely speculative. Schönswetter et al. (2005) defined the potential refugial zones in the Alps based on the paleoenvironmental and geological data and subsequently tested the existence of these zones by comparison with the phylogeographic patterns of 12 mountain species. This combined approach allowed major refugial areas to be identified (Fig. 1). However, some doubts still remain about the existence of refugia in the middle section of the alpine massif, which was on ice-free mountaintops that likely protruded above the glaciers. Only organisms adapted to severe high-elevation conditions could survive there. This so-called 'nunatak hypothesis' has gained some support with molecular evidence suggesting the glacial persistence of some high-mountain plant and animal species in nunatak refugia (Schönswetter and Schneeweiss 2019). In particular, some long-lived plant species, frequently diploid, that had adapted to cold conditions and with a high ability for the clonal growth might have survived glaciation periods in the peripheral refugia or on nunataks (Favarger 1972; Nève and Verlaque 2010). In terms of genetic patterns, isolated nunatak populations should presumably be characterized by clear differentiation and distinctive diversity that may manifest with private alleles/haplotypes that are restricted to refugial populations (Schönswetter and Schneeweiss 2019). However, these genetic signatures of nunatak survival may be difficult to detect because of the genetic swamping that is likely to occur during (re)colonization process (Gabrielsen et al. 1997; Schneeweiss and Schönswetter 2011; Schönswetter and Schneeweiss 2019).

The fossil record of the Alpine flora is scarce due to the lack of conditions suitable for the accumulation of macroremains at the highest elevations (Lang 1994). The available evidence does not provide definite support for continuous in situ existence of high-elevation species throughout the time with the greatest ice-sheet area. Paleodistribution models can fill this gap by supplying an independent test of the predictions of genetic models. Modelling of past climates and species distributions may provide complementary insight into their complex histories (Gavin et al. 2014). Species distribution models (SDMs) assume that the climatic niche of a species can be based on present-day observations and that it remains the same over the time, which enables the climate-based reconstruction of the potential distributional range of the species in the past using paleoclimatic data (Wiens and Graham 2005). However, since SDMs relay on climatic variables only, the results gained via SDMs should be tested against the other sources including genetic data and fossil records.

Salix serpillifolia Scop. is a very resilient species and was described by Ellenberg (1988) as "the only woody plant to feel at home in the region of eternal snow". This slow-growing, dioecious, diploid, procumbent dwarf willow is endemic to the Alps (Dostál 1989; Rechinger 1992; Skvortsov 1999; Kosiński et al. 2019). It inhabits severe alpine vegetation zone and even ledges in the subnival belt, up to $3200 \mathrm{~m}$ a.s.l., where it is found mainly on a base-rich substrate in the habitats of grassland communities, screes and rock crevices. Despite its small size, it is supposed that 
Table 1 Sampled populations of Salix serpillifolia; $N$-number of sampled individuals (nSSR/cpSSR)

\begin{tabular}{|c|c|c|c|c|c|}
\hline Population ID & Locality & $N$ & Longitude & Latitude & Elevation $(\mathrm{m})$ \\
\hline 1 & France, Western Alps, Maritime Alps, Mt Bonette & $28 / 17$ & 6.833 & 44.335 & 2542 \\
\hline 2 & France, Western Alps, Cottian Alps, Col d'Izoard & $28 / 12$ & 6.737 & 44.815 & 2293 \\
\hline 3 & France, Western Alps, Graian Alps, Col du Galibier & $30 / 15$ & 6.403 & 45.062 & 2599 \\
\hline 4 & France, Western Alps, Graian Alps, Col de l'Iseran & $29 / 15$ & 7.042 & 45.401 & 2591 \\
\hline 5 & France, Western Alps, Graian Alps, Little St Bernard Pass & $29 / 13$ & 6.875 & 45.665 & 2193 \\
\hline 6 & Switzerland, Western Alps, Bernese Alps, Crans-Montana, las Violetes & $30 / 10$ & 7.498 & 46.342 & 2233 \\
\hline 7 & $\begin{array}{l}\text { Switzerland, Western Alps, Bernese Alps (Uri Alps), Furka Pass, Rhone } \\
\text { Glacier }\end{array}$ & $28 / 15$ & 8.389 & 46.579 & 2384 \\
\hline 8 & Switzerland, Western Alps, Bernese Alps (Uri Alps), Oberalp Pass & $30 / 14$ & 8.673 & 46.660 & 2075 \\
\hline 9 & Switzerland, Western Alps, Glarus Alps, Pizol & $30 / 15$ & 9.434 & 46.980 & 2215 \\
\hline 10 & Switzerland, Central Eastern Alps, Western Rhaetian Alps, Fuorn Pass & $0 / 11$ & 10.293 & 46.639 & 2157 \\
\hline 11 & $\begin{array}{l}\text { Italy, Central Eastern Alps, Sarntal Alps, Königsangerspitze (Monte } \\
\text { Pascolo) }\end{array}$ & $30 / 14$ & 11.581 & 46.708 & 2318 \\
\hline 12 & Italy, Southern Limestone Alps, Dolomites, Rosengarten & $30 / 15$ & 11.617 & 46.416 & 2236 \\
\hline 13 & Italy, Southern Limestone Alps, Dolomites, Rolle Pass & $0 / 4$ & 11.795 & 46.308 & 2267 \\
\hline 14 & Italy, Southern Limestone Alps, Adamello-Presanella Alps, Mt Presanella & $30 / 5$ & 10.58 & 46.239 & 2573 \\
\hline 15 & $\begin{array}{l}\text { Italy, Southern Limestone Alps, Adamello-Presanella Alps, Croce Domini } \\
\text { Pass }\end{array}$ & $0 / 5$ & 10.414 & 45.915 & 2086 \\
\hline 16 & Italy, Southern Limestone Alps, Bergamasque Prealps, Mt Corna Piana & $0 / 10$ & 9.811 & 45.941 & 2180 \\
\hline 17 & Austria, Northern Limestone Alps, Lechtal Alps, Mt Hahntennjoch & $0 / 11$ & 10.665 & 47.296 & 2200 \\
\hline
\end{tabular}

it can live for over 100 years (Ellenberg 1988). It forms prostrate mats on exposed mountain slopes and ridges and produces creeping stems with the capacity of rooting, and thereby, clonal growth (personal observations). Fragmentation of plant material and re-rooting further down the slope increases the probability of its survival in a harsh and unstable environment.

In the present study, we investigated the spatial genetic structure of the Alpine endemic woody plant, S. serpillifolia. So far, most studies dedicated to alpine or subalpine calcicolous species has been focused on the herbaceous plants (e.g. Stehlik et al. 2002a, b; Stehlik 2002; Naciri and Gaudeul 2007; Schönswetter et al. 2009; Schneeweiss and Schönswetter 2010; Schönswetter and Schneeweiss 2019). Alpine zones are important areas of global biodiversity because they host a high diversity of cold-adapted specialists, including many endemic species. Nevertheless, global warming is expected to cause an upward shifting of plant species in the high mountain systems and, consequently, the habitats available for the alpine and nival plants may be significantly limited leading to extinction of some of them (Rangwala and Miller 2012; Steinbauer et al. 2018; Asse et al. 2018). Thus, population genetic data gained for alpine species may be useful not only in determining historical events but also in predicting the ability of taxa to respond to current climate change.

In this study, genetic analyses were used with the aim of answering the following questions: (1) What is the pattern of geographic distribution of the genetic diversity of
S. serpillifolia? (2) Is there any congruence between this pattern and those reported for other European obligate highmountain plant species? (3) Is there evidence for nunatak survival, which is expected to be plausible for this species given its current habitat requirements?

\section{Materials and methods}

\section{Sampling, DNA extraction and genotyping}

Seventeen populations of $S$. serpillifolia were sampled across the Alps (Table 1; Fig. 1). Leaves were collected from plants that were separated by at least $20 \mathrm{~m}$, as willows from the $S$. retusa group reproduce vegetatively by the rooting of the stems (Rechinger 1957; Hörandl et al. 2002; Koblížek 2006). Samples of these populations were deposited at the Herbarium of the Institute of Dendrology, Polish Academy of Sciences (KOR). Genomic DNA was extracted from dried leaf tissues following a CTAB protocol (Doyle and Doyle 1987).

Twelve populations with a sufficient number of sampled individuals were used for the screening of polymorphisms at the nuclear microsatellite loci (nSSRs) (Table 1). Initially, a total of $30 \mathrm{nSSRs}$ markers originally designed for Salix sp. (Barker et al. 2003; Stamati et al. 2003) and Populus sp. (Tuskan et al. 2004; Carvalho et al. 2010) were tested. Then, a set of ten markers was selected (Online Resource 1), as they gave repeatable, high-quality amplification products; these 
were gSIMCT024, gSIMCT035, gSIMCT041, gSIMCT052 (Stamati et al. 2003), ORPM-028, ORPM-030, ORPM-202 (Tuskan et al. 2004), ASP322 (Carvalho et al. 2010), GCPM 1255, and GCPM 1812 (Zeng et al. 2016). The PCR was performed in two multiplexes in a total volume of $10 \mu \mathrm{l}$ using Qiagen Multiplex PCR Kit (Qiagen, Hilden, Germany) according to the manufacturer's instructions. Amplification was conducted according to the thermal profile presented in Tuskan et al. (2004) and Stamati et al. (2003) (Online Resource 1).

All sampled populations were screened for their chloroplast microsatellite polymorphisms (cpSSRs) using three primer pairs, CSU01, CSU05 and CSU07, developed for $S$. reinii (Lian et al. 2003). The samples were amplified in PCR reactions in a total volume of $10 \mu \mathrm{l}$ using Qiagen Multiplex PCR Kits (Qiagen, Hilden, Germany) under conditions recommended by the manufacturer.

PCR products of both nSSRs and cpSSRs were separated on an Applied Biosystems 3130 Genetic Analyzer (Thermo Fisher Scientific, Waltham, USA) with an internal size standard, GeneScan ${ }^{\mathrm{TM}} 500$ LIZ $^{\circledR}$. Genotypes were scored manually using GeneMapper 4.0 software (Thermo Fisher Scientific, Waltham, USA). Raw2Gen software (I.J. Chybicki, Kazimierz Wielki University, Poland, unpubl. data) was used to bin the observed nSSR and cpSSR allele sizes into representative discrete alleles according to the method of Idury and Cardon (1997).

\section{Data analysis}

\section{Nuclear SSR genetic diversity and differentiation}

Linkage disequilibrium among the nSSR loci for each population was estimated using FSTAT 2.9.4 with 1500 permutations (Goudet 1995, 2003). Deviation from Hardy-Weinberg equilibrium was tested using an exact test implemented in GenePop v. 4.0 (Raymond and Rousset 1995). The multilocus parameters of genetic diversity for populations, including average number of alleles (A), private alleles per population $\left(P_{\mathrm{A}}\right)$, average number of effective alleles $\left(A_{\mathrm{E}}\right)$, allelic richness $\left(A_{\mathrm{R}}\right)$, expected heterozygosity $\left(H_{\mathrm{E}}\right)$, observed heterozygosity $\left(H_{\mathrm{O}}\right)$ and inbreeding coefficient $\left(F_{\mathrm{IS}}\right)$ were estimated using GenAlEx v.6.2 (Peakall and Smouse 2012). The null alleles frequency (Null) and multilocus inbreeding coefficient including 'null alleles' correction $\left(F_{\mathrm{IS}} \mathrm{Null}\right)$ were estimated following an individual inbreeding model (IIM) implemented in INEst 2.2 (Chybicki and Burczyk 2009). Using the Deviance Information Criterion (DIC), we compared the full model ('nfb'; null alleles, and genotyping failures, $F_{\text {IS }}>0$ ) with a random mating model ('nb'; null alleles and genotyping failures, under an assumption of $F_{\text {IS }}=0$ ) to assess the factors affecting the homozygosity level in populations. The analysis was run with 500,000 MCMC cycles, with every 200th cycle sampled and a burn-in of 50,000 .

The overall genetic differentiation among populations, Wright's fixation index $\left(F_{\mathrm{ST}}\right)$ (Wright 1931), was assessed using GenAlEx and the significance of $F_{\mathrm{ST}}$ was calculated with 10,000 permutations. Additionally, the ENA correction method excluding null alleles ( $F_{\mathrm{ST}} \mathrm{ENA}$ ) was applied to recalculate multilocus $F_{\mathrm{ST}}$ after 9999 replicates in FreeNA, as null alleles may overestimate the value of $F_{\mathrm{ST}}$ (Chapuis and Estoup 2007). Finally, pairwise population comparisons based on $F_{\mathrm{ST}}$ were performed in Arlequin v. 3.1 and tested with a permutation test.

Evidence of a recent bottleneck was evaluated using the $M$-ratio method (Garza and Williamson 2001) implemented in INEst 2.2. The mean ratio was calculated as $M=k / r$, where ' $k$ ' is the total number of alleles and ' $r$ ' is the overall range in allele size for each population. The $M$-ratio value is expected to be lower in populations that have experienced a bottleneck than in populations in mutation-drift equilibrium (Garza and Williamson 2001). The analysis was run under the two-phase mutation model (TPM) with the proportion of multi-step mutations (pg) set as 0.22 and the mean size of multi-step mutations $(\delta \mathrm{g})$ as 3.1 according to recommendations of Peery et al. (2012). The reduction in the $M$-ratio was verified by comparing the mean observed $M$-ratio $(M)$ to the simulated $M$-ratio generated under mutation-drift equilibrium (MReq). To evaluate the significance of a deficiency in the $M$-ratio, the Wilcoxon signed-rank test based on coalescent simulations consisting of $10^{6}$ iterations was applied.

\section{Chloroplast SSR genetic diversity}

Haplotypes were defined as unique combinations of size variants across the cpSSRs. HAPLOTYPE ANALYSIS 1.05 (Eliades and Eliades 2009) was used to calculate withinpopulation genetic diversity, number of different haplotypes $(A)$, number of private haplotypes $\left(P_{\mathrm{H}}\right)$, effective number of haplotypes $\left(N_{\mathrm{E}}\right)$, haplotypic richness $\left(H_{\mathrm{R}}\right)$, Nei's index of genetic diversity $\left(H_{\mathrm{E}}\right)$, mean genetic distance between individuals $\left(D_{\mathrm{sh}}^{2}\right)$ (Goldstein et al. 1995) and genetic differentiation $\left(F_{\mathrm{ST}}\right)$ among populations (Finkeldey and Murillo 1999).

\section{Geographic patterns of differentiation}

A model-based Bayesian clustering approach was used to investigate the geographic pattern of genetic differentiation at nSSRs among populations using STRUCTURE 2.3.3 (Pritchard et al. 2000). The analysis was performed based on a non-spatial admixture model with correlated allele frequencies without prior information of population location. Ten independent repetitions for each number of groups $(K)$ ranging from 1 to 13 were performed with a burn-in of $10^{5}$ 
steps, followed by $2 \times 10^{5} \mathrm{MCMC}$ iterations. The alignment of the results across ten replicates of analyses was assessed using CLUMPAK (Kopelman et al. 2015) and the best number of clusters was determined according to Evanno's $\Delta K$ method (Evanno et al. 2005). To infer the population genetic structure at linked cpSSRs, a spatial genetic mixture model implemented in BAPS was used (Corander et al. 2008). The optimal number of $K$ clusters was used with the clustering of groups option in which populations with known coordinates are used as clustering units. After the testing stage, an analysis was run for ten replicates of $K$ ranging between 1 and 18 .

To identify potential genetic barriers among populations Monmonier's maximum-difference algorithm implemented in BARRIER 2.2 was used (Manni et al. 2004). The analysis was conducted using Reynold's distance matrix and the geographical coordinates of sample sites. The significance of barriers was evaluated by bootstrapping with 1000 replications of 1000 distance matrices generated by the SEQBOOT and GENDIST programmes of PHYLIP package 3.696 (Felsenstein 1989).

The isolation-by-distance (IBD) analysis was performed in GenAlEx by testing the correlation between the matrix of pairwise Slatkin's linearized $F_{\mathrm{ST}}$ values (Slatkin 1995) with ENA correction and the pairwise geographical distance matrix using the Mantel test, and the significance of IDB was assessed with 1000 permutations.

\section{Species distribution modelling}

To evaluate the effect of past and present climatic conditions on the geographic range of S. serpillifolia, species distribution modelling that was based on the maximum entropy approach implemented in MaxEnt 3.4.1 was applied (Phillips et al. 2004; Elith et al. 2011). The climatic information available in the WorldClim database (Hijmans et al. 2005) was used to construct the models of the potential distribution of this species at the present time (1960-1990; PRE) and at the last glacial maximum (c. 22,000 year BP; LGM). To construct the models for the current species range, 19 bioclimatic variables were used at a 30 arc-sec resolution (Hijmans et al. 2005) (Online Resource 2). The LGM layers were based on the Community Climate System Model (CCSM3) at a 2.5 arc-min resolution (Collins et al. 2006). Analyses were performed as a bootstrap with 10 replicates. The 'random seed' option was applied, and $20 \%$ of the data were used to be set aside as the test points. The maximum number of iterations was set to 10,000 and the convergence threshold to 0.00001 . To evaluate the model accuracy, the receiver operating characteristic (ROC) curve and value of area under the curve (AUC) were used. An AUC value close to 0.5 indicates that the model is weak, and a value close to 1.0 suggests that the model has excellent performance. The list of species occurrence records that was used to model the range of S. serpillifolia was based on the data presented in Kosiński et al. (2017) and the ZOBODAT database (http:// www.zobodat.at) (Online Resource 3).

\section{Results}

\section{Genetic diversity}

\section{Nuclear microsatellites}

Detailed information on the polymorphisms of the nSSR loci that were used in this study is presented in Online Resource 1. In total, 150 alleles were identified among 351 individuals at ten nSSR loci. SSR loci showed a wide level of variability ranging from 5 (gSIMCT041) to 29 (gSIMCT052) alleles with an average of 15 alleles per locus. Null alleles were detected in all loci, with an average frequency approaching 0.082 (Online Resource 1).

Genetic variation at the nSSR loci of the analysed populations of $S$. serpillifolia was relatively low, with the expected heterozygosity reaching an average $H_{\mathrm{E}}=0.595$ and average number of alleles $A=6.758$ (Table 2). The highest $H_{\mathrm{E}}$ was found in population $12\left(H_{\mathrm{E}}=0.723\right)$ and the lowest in population $8\left(H_{\mathrm{E}}=0.481\right)$. Allelic richness $\left(A_{\mathrm{R}}\right)$ was comparable in most of the populations, except for in populations 12 and 9, in which the highest values of $A_{\mathrm{R}}$ were noted, reaching 8.711 and 8.191, respectively (Table 2). Private alleles were noted in all populations, but the highest number of private alleles ( 9 and 10) was observed in populations 9 and 12 , respectively. Null alleles were observed in all populations, and their frequency ranged from 0.041 to 0.127 with an average of 0.086 . A significant excess of homozygotes $(p<0.001)$ was detected in all populations and generally high values of inbreeding coefficient $\left(F_{\text {IS }}\right)$ were noted, ranging from 0.114 to 0.358 ( 0.250 on average). The $F_{\text {IS }}$ value that was estimated with a 'null alleles' correction $\left(F_{\mathrm{IS}} \mathrm{Null}\right)$ was lower in most of the populations (0.069 on average), suggesting that the observed deficiency of heterozygotes may result not only from inbreeding but also from the presence of null alleles, especially in populations $1,4,8$ and 14 , where only null alleles had a substantial impact on $F_{\text {IS }}$ estimation (Table 2).

Estimations of the global level of genetic differentiation with and without the ENA correction were almost the same and attained values of $F_{\mathrm{ST}} \mathrm{ENA}=0.074$ (CI 0.054-0.107) and $F_{\mathrm{ST}}=0.075$ (CI 0.056-0.103), respectively. The population pairwise $F_{\mathrm{ST}}$ ranged from 0.0086 (between populations 2 and 7) to 0.232 (between populations 1 and 11), and 63 of 65 comparisons were significant $(p<0.05)$; non-significant differentiation was observed between populations 2 and 7 , and between populations 4 and 6 (data not shown). 
Table 2 Summary of genetic variability estimated for populations of Salix serpillifolia across ten nSSR loci; population abbreviations as in Table 1
Table 3 Results of the $M$-ratio test under the two-phase model (TPM) estimated for Salix serpillifolia populations across ten polymorphic nSSR loci; population abbreviations as in Table 1

\begin{tabular}{lllllllllll}
\hline ID & $N$ & $A$ & $A_{\mathrm{E}}$ & $A_{\mathrm{R}}$ & $P_{\mathrm{A}}$ & $H_{\mathrm{O}}$ & $H_{\mathrm{E}}$ & $F_{\text {IS }}$ & $F_{\text {IS }}$ Null & Null \\
\hline 1 & 29 & 6.000 & 3.207 & 5.854 & 0.100 & 0.424 & 0.601 & $\mathbf{0 . 3 5 8} *$ & 0.072 & 0.127 \\
2 & 30 & 7.000 & 3.267 & 6.670 & 0.300 & 0.543 & 0.594 & $0.118^{*}$ & 0.050 & 0.041 \\
3 & 29 & 6.600 & 3.097 & 6.326 & 0.300 & 0.480 & 0.628 & $0.290^{*}$ & 0.076 & 0.089 \\
4 & 30 & 6.600 & 2.998 & 6.307 & 0.200 & 0.442 & 0.577 & $\mathbf{0 . 2 5 9} *$ & 0.040 & 0.099 \\
5 & 30 & 6.300 & 2.677 & 6.024 & 0.000 & 0.460 & 0.539 & $0.114^{*}$ & 0.048 & 0.062 \\
6 & 30 & 6.400 & 2.867 & 6.150 & 0.400 & 0.490 & 0.600 & $0.215^{*}$ & 0.048 & 0.083 \\
7 & 28 & 5.900 & 2.992 & 5.775 & 0.200 & 0.455 & 0.544 & $0.258^{*}$ & 0.109 & 0.092 \\
8 & 30 & 5.300 & 2.451 & 5.093 & 0.100 & 0.410 & 0.481 & $\mathbf{0 . 2 3 7} *$ & 0.053 & 0.081 \\
9 & 30 & 8.600 & 4.397 & 8.191 & 0.900 & 0.507 & 0.710 & $0.332^{*}$ & 0.066 & 0.113 \\
11 & 25 & 5.800 & 3.076 & 5.800 & 0.500 & 0.448 & 0.523 & $0.139^{*}$ & 0.062 & 0.036 \\
12 & 30 & 9.200 & 4.545 & 8.711 & 1.000 & 0.492 & 0.723 & $0.356^{*}$ & 0.171 & 0.075 \\
14 & 30 & 7.400 & 3.198 & 6.999 & 0.200 & 0.485 & 0.619 & $\mathbf{0 . 3 0 2} *$ & 0.038 & 0.120 \\
Average & & $\mathbf{6 . 7 5 8}$ & $\mathbf{3 . 2 3 1}$ & $\mathbf{6 . 4 9 2}$ & $\mathbf{0 . 3 5 0}$ & $\mathbf{0 . 4 7 0}$ & $\mathbf{0 . 5 9 5}$ & $\mathbf{0 . 2 5 0}$ & $\mathbf{0 . 0 6 9}$ & $\mathbf{0 . 0 8 6}$ \\
\hline
\end{tabular}

$N$ number of analysed individuals, $A$ average number of alleles per locus, $A_{E}$ effective number of alleles, $A_{R}$ allelic richness based on minimum sample size of 25 individuals, $P_{A}$ average number of private alleles per locus, $H_{O}$ observed heterozygosity, $H_{E}$ expected heterozygosity, $F_{I S}$ inbreeding coefficient (in bold: $F_{\text {IS }}$ estimation may result only from presence of the null alleles, ' $*$ ' deviation from Hardy-Weinberg equilibrium at $p<0.05,), F_{I S} N u l l$ inbreeding coefficient including "null alleles" correction, Null null allele frequencies

\begin{tabular}{llll}
\hline ID & MR & MReq & $p$ value \\
\hline 1 & 0.692 & 0.784 & 0.1392 \\
2 & 0.705 & 0.773 & 0.2477 \\
3 & 0.563 & 0.780 & $\mathbf{0 . 0 3 2 4}$ \\
4 & 0.677 & 0.757 & 0.1249 \\
5 & 0.595 & 0.776 & $\mathbf{0 . 0 1 8 5}$ \\
6 & 0.627 & 0.769 & 0.0660 \\
7 & 0.168 & 0.542 & $\mathbf{0 . 0 0 0 0}$ \\
8 & 0.576 & 0.773 & $\mathbf{0 . 0 3 7 2}$ \\
9 & 0.613 & 0.751 & 0.1170 \\
11 & 0.563 & 0.752 & $\mathbf{0 . 0 1 9 8}$ \\
12 & 0.616 & 0.741 & 0.0528 \\
14 & 0.830 & 0.777 & 0.9214 \\
\hline
\end{tabular}

$M R$ the mean observed $M$-ratio, MReq the $M$-ratio generated under mutation-drift equilibrium, $p$ value probability of significant test for the deficiency in $M$-ratio based on Wilcoxon signed-ranks test

Significant $p$ values are bolded
The mean observed $M$-ratio ranged from 0.168 to 0.830 . It was significantly $(p<0.05)$ lower than the simulated equilibrium distribution of the $M$-ratio (MReq) in five populations (Table 3). Specifically, evidence for a recent bottleneck was detected in populations from the Graian Alps (populations 3 and 5), Bernese Alps (populations 7 and 8) and the Italian part of the Central Eastern Alps (population 11).

\section{Chloroplast microsatellites}

Chloroplast microsatellites displayed a high level of variation: the three cpSSR loci used in our study yielded four (CSU01), six (CSU05) and nine (CSU07) size variants differing by a single nucleotide. Together, the cpSSR size variants were combined into 53 haplotypes. Generally, the haplotypes occurred at low frequencies; only a single haplotype reached a frequency of $10.4 \%$ and three attained a frequency of 5-10\%; the remaining haplotypes occurred at frequencies below 5\%. A summary of the haplotypic diversity of populations is provided in Table 4 . The highest total number of haplotypes per population was 10 , and it was detected in populations 7 and 11 (Central and Eastern Alps, respectively), while population 17 was characterized by the presence of only two haplotypes, which was the lowest number noted in the whole dataset. Private haplotypes were noted in most of the populations (Table 4). In population 7, six out of the ten haplotypes detected were the private ones, which was the highest number noted. Generally, more private haplotypes were found in populations from the Western Alps than in populations from the Eastern Alps. In most populations, the effective number of haplotypes $\left(N_{\mathrm{E}}\right)$ was not very different from the total number of haplotypes $(A)$, i.e., $6.824 v s .5 .278$ on average. High genetic diversity $\left(H_{\mathrm{E}}\right)$ was noted and ranged from 0.436 (population 17) to 1.0 in population 15, in which five of the analysed individuals had their own distinct haplotypes. The mean intrapopulation genetic distance ranged from $D_{\text {sh }}^{2}=0.582$ in population 17 up to 8.206 in population 10 , with the average value amounting to 2.949 . The overall genetic differentiation among populations was moderate and reached $F_{\mathrm{ST}}=0.198$. The highest 
Table 4 Summary of genetic variability estimated for populations of Salix serpillifolia across cpSSR loci; population abbreviations as in Table 1

\begin{tabular}{llllllll}
\hline ID & $N$ & $A$ & $P_{\mathrm{H}}$ & $N_{\mathrm{E}}$ & $H_{\mathrm{R}}$ & $H_{\mathrm{E}}$ & $D_{\text {sh }}^{2}$ \\
\hline 1 & 17 & 9 & 2 & 6.149 & 2.401 & 0.890 & 2.926 \\
2 & 12 & 8 & 3 & 7.200 & 2.636 & 0.939 & 4.606 \\
3 & 15 & 8 & 2 & 6.818 & 2.503 & 0.914 & 3.917 \\
4 & 15 & 9 & 0 & 6.429 & 2.472 & 0.905 & 1.244 \\
5 & 13 & 7 & 2 & 5.121 & 2.299 & 0.872 & 2.607 \\
6 & 10 & 4 & 1 & 1.923 & 1.200 & 0.533 & 0.919 \\
7 & 15 & 10 & 6 & 8.333 & 2.666 & 0.943 & 6.521 \\
8 & 14 & 7 & 2 & 4.667 & 2.193 & 0.846 & 2.421 \\
9 & 15 & 9 & 2 & 6.429 & 2.472 & 0.905 & 4.171 \\
10 & 11 & 7 & 3 & 5.762 & 2.479 & 0.909 & 8.206 \\
11 & 14 & 10 & 2 & 7.000 & 2.581 & 0.923 & 2.465 \\
12 & 15 & 9 & 1 & 7.759 & 2.609 & 0.933 & 2.635 \\
13 & 4 & 3 & 0 & 2.667 & 2.000 & 0.833 & 0.611 \\
14 & 5 & 3 & 0 & 2.273 & 1.600 & 0.700 & 0.800 \\
15 & 5 & 5 & 0 & 5.000 & 3.000 & 1.000 & 2.200 \\
16 & 10 & 6 & 2 & 4.545 & 2.267 & 0.867 & 3.296 \\
17 & 11 & 2 & 0 & 1.658 & 0.788 & 0.436 & 0.582 \\
Average & & $\mathbf{6 . 8 2 4}$ & $\mathbf{1 . 6 4 7}$ & $\mathbf{5 . 2 7 8}$ & $\mathbf{2 . 2 4 5}$ & $\mathbf{0 . 8 4 4}$ & $\mathbf{2 . 9 4 9}$ \\
\hline
\end{tabular}

$N$ number of analysed individuals, $A$ number of different haplotypes, $P_{H}$ number of private haplotypes, $N_{E}$ effective number of haplotypes, $H_{R}$ haplotypic richness, $H_{E}$ genetic diversity and $D_{s h}^{2}$ mean genetic distance between individuals values of pairwise $F_{\mathrm{ST}}$ were found between populations 6 and $17(0.109)$ and populations 14 and 17 (0.101). The lowest differentiation was noted between populations 1 and 12 (0.006) (data not shown).

\section{Spatial genetic structure}

A weak isolation by distance was revealed by the Mantel test based on the genetic (nSSRs) and geographic distance matrices $\left(R^{2}=0.13, p=0.02\right)$ (Online Resource 4). We did not find a similar correlation for the cpSSR dataset.

Monmonier's algorithm identified five genetic barriers among the analysed populations (Fig. 2a), but only the first three barriers received meaningful bootstrap support. These three strongest barriers were detected for the isolated population 1 from the Maritime Alps and the most north-easterly located population 11 from the Sarntal Alps. The distinct characteristics of populations 1 and 11 were repeatedly noted in the other analyses (Figs. 2, 3). The third barrier divided the Alps into western and eastern domains. The weakest barrier separated the most westerly situated population 3 from the remaining western Alpine populations.

The Bayesian clustering of the nSSRs (Fig. 2) revealed that the best supported number of clusters was $K=3$ (Fig. 2c). Some geographic pattern of differentiation corresponding to the main regions of the Alps was detected (Fig. 2a, b). The most easterly situated populations 11 and 2 were mostly assigned to cluster I and they were the most distinct from the rest of the populations. In particular, population 11 from the Central Eastern Alps (the Sarntal Alps) showed only limited overlap with the gene pools of other inferred clusters. Most of the populations from the Western Alps (populations 2-8) and the single population from the Southern Limestone Alps (population 14) formed a separate and rather homogenous group belonging to cluster II with the high individual proportion of the memberships ranging from 66 to $98 \%$. Only populations 3 and 14 from this group presented high admixture with other gene pools. Interestingly, the most northerly located population 9 (the Glarus Alps) showed a genetic mixture of the western and eastern alpine gene pools (cluster I and III, respectively) (Fig. 2a).

The BAPS clustering for the cpSSRs did not reveal any clear geographically-dependent pattern (Fig. 3). The most likely number of clusters inferred was $K=11$, and most populations consisted of individuals showing genetic affinities with different clusters. Considering the major cluster only, some geographic specificity appeared and indicated the distinctiveness of the populations from the Western and Eastern Alps. However, both the western and eastern distribution domains were inhabited with populations showing a large intermixing of a few clusters that occurred in those areas (Fig. 3a, b). Interestingly, in some populations, there were individuals that represented exclusive BAPS clusters, which were not detected elsewhere. Especially, the monotypic population 6 and the polytypic populations 7 and 8 , all three from the inner part of the 
Fig. 2 Population genetic structure of Salix serpillifolia, as based on the nSSR loci; $\mathbf{a}$ proportion of membership of individuals from a given population in each of the three clusters as indicated by the Bayesian clustering analysis (STRUCTU $\mathrm{RE})$; red lines: genetic boundaries, as detected by BARRIER and obtained with Monmonier's algorithm, which was based on Reynolds' genetic distance (numbers represent the bootstrap values indicating support for the respective boundaries), $\mathbf{b}$ barplot proportion of membership of each individual in the three assumed clusters $(K=3)$, c chart of $\Delta K$ values. Refugial areas as explained in Fig. 1

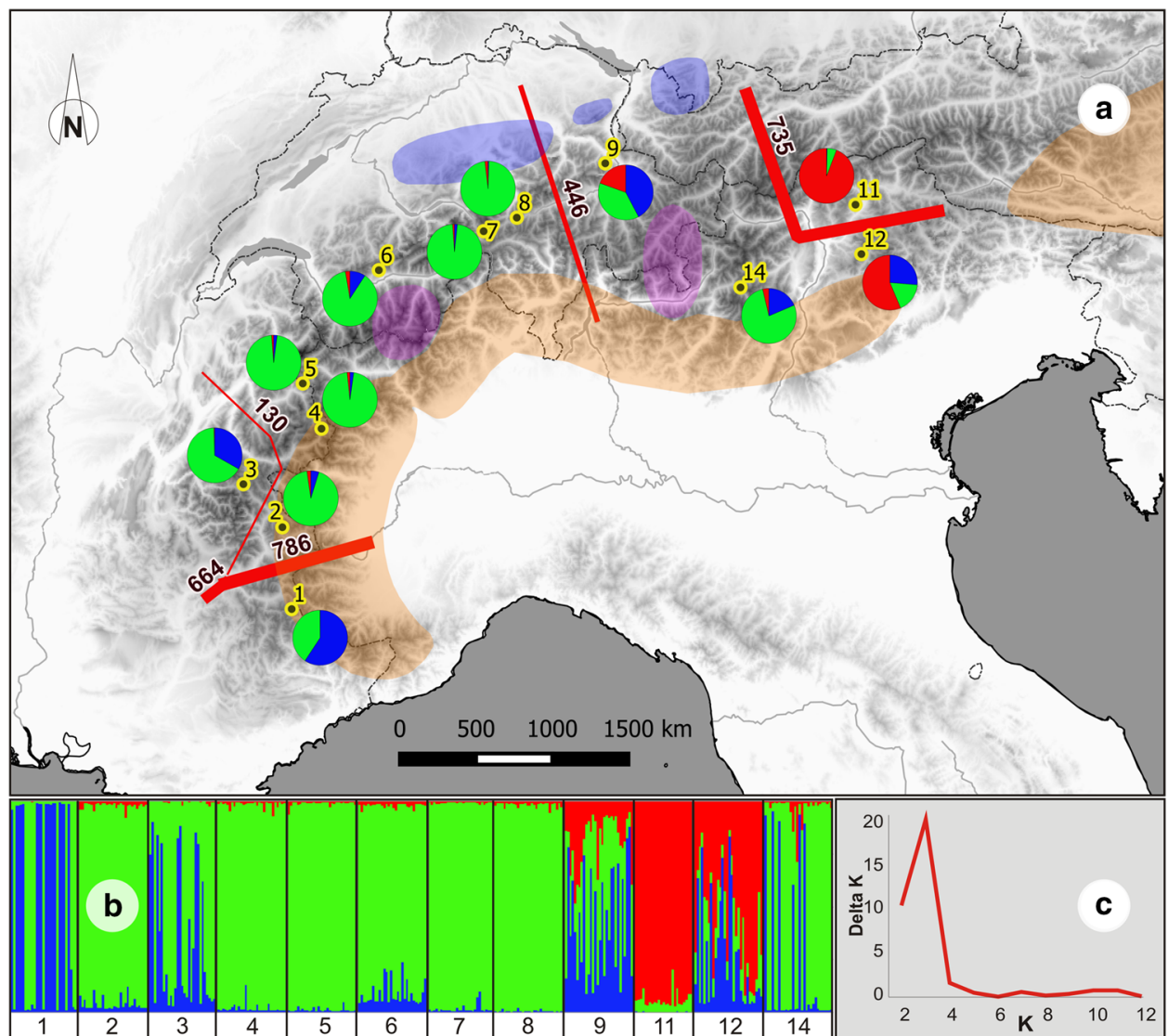

massif, were characterized by unique genetic structure. In populations 7 and 8 some individuals formed own clusters, while the remaining ones were grouped into clusters found in the Western and Eastern Alps (populations 7 and 8 , respectively).

\section{Species distribution modelling}

Predicted current distribution of S. serpillifolia estimated by the MaxEnt software primarily covers the Alps, with more favourable climatic conditions in the western part of the Alps (Fig. 4a). The model-based distribution of S. serpillifolia during the LGM is smaller than the contemporary one and shifted to the south-west: it covers the Apuan Alps in the Northern Apennines and the south-western parts of the Alps, including the Maritime, Ligurian, Cottian and Provence Alps (Fig. 4b). With lower suitability, this projected range includes the mountain areas of the central and southern parts of the Swiss Alps, and, to a lesser extent, areas of the Central Eastern Alps and the Southern Limestone Alps. The most important climatic factor that shapes the putative range of $S$. serpillifolia is the mean temperature of the warmest quarter (58.6\%) (Online Resource 2).

\section{Discussion}

\section{Diversity and spatial genetic structure of Salix serpillifolia}

Our study shows that $S$. serpillifolia harbours moderate genetic and allelic diversity at nuclear microsatellites $\left(H_{\mathrm{E}}=0.644 ; A=10.933\right.$; at the species level, not presented in the results section), yet this diversity was comparable to previously observed estimations in the arctic-alpine willow species, $S$. lanata, $S$. lapponum and $S$. herbacea ( $H_{\mathrm{E}}=0.706,0.703,0.527 ; A=8.4,12.4,5.8$, respectively) (Stamati et al. 2007). Considerable diversity was reported at chloroplast microsatellites, but they had lower allelic variability $\left(H_{\mathrm{E}}=0.844 ; A=6.824\right.$. $)$. However, the number of size variants that were obtained from the three cpSSR loci in S. serpillifolia was nearly two times higher than that reported earlier for $S$. reinii (19 and 10, respectively) (Lian et al. 2003).

According to $M$-ratio, five populations (3, 5, 7, 8 and 11) experienced a bottleneck effect. Generally, detection of demographic decline with $M$-ratio indicates that the bottleneck lasted several generations and population has recovered (Williamson-Natesan 2005). In the case of $S$. 
Fig. 3 Population-based genetic structure of Salix serpillifolia, as determined by the cpSSR loci; a pie charts representing the average per cluster assignment values for all individuals from a given population based on the individual-based clustering algorithm in BAPS $(K=11)$ and the refugial areas in the Alps, as defined by Schönswetter et al. (2005a); b bar plot with the assignment analysis in BAPS $(K=11)$. Refugial areas as explained in Fig. 1

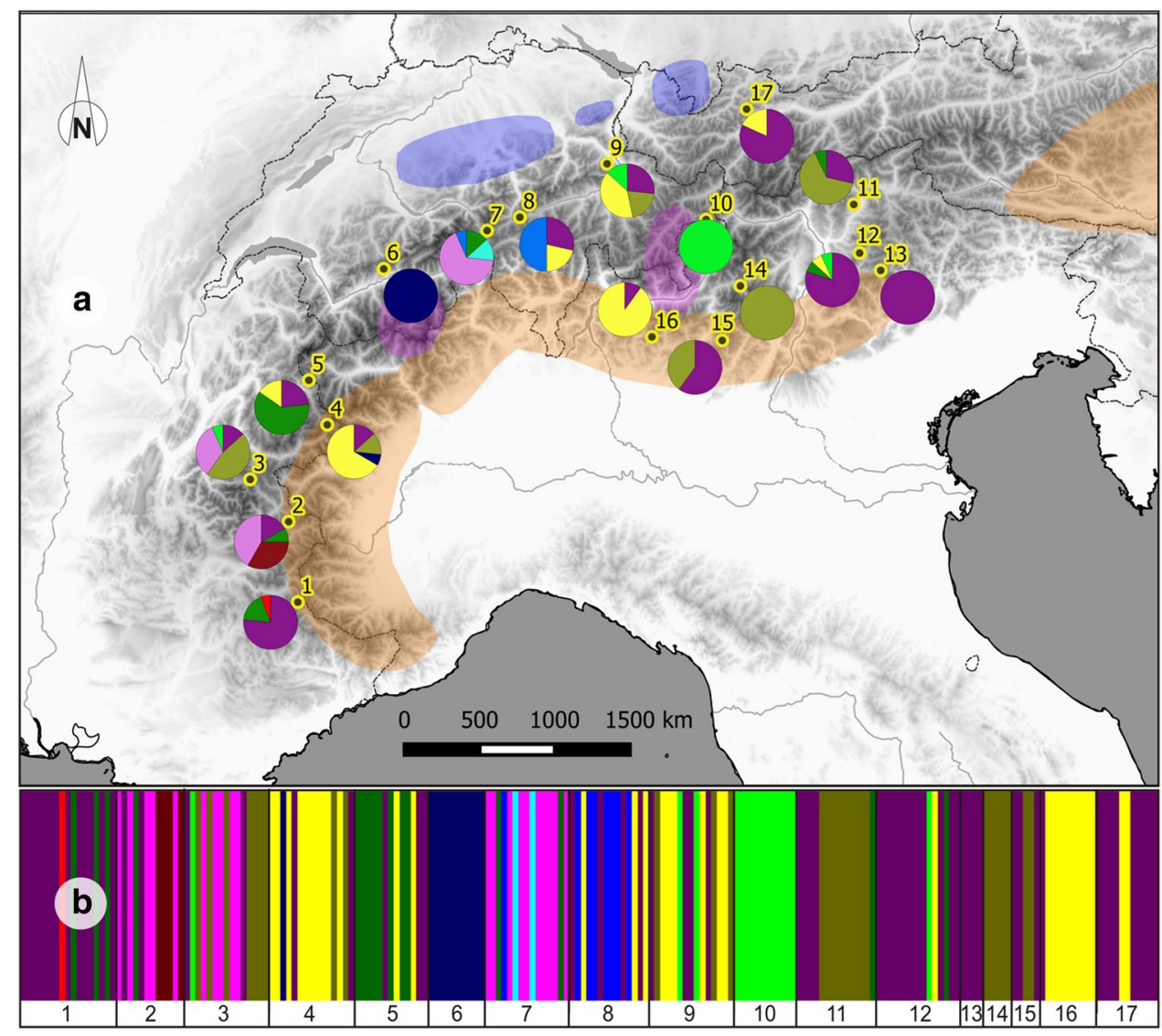

serpillifolia, these results suggest that population decline might have been related to the severe conditions prevailing during the LGM. As purely stochastic process, bottleneck leads to long-term reduction of effective population sizes. Consequently, it results in loss of allelic and gene diversity and may distort the inter-population differentiation pattern.

A significant among-population component of variation $\left(F_{\mathrm{ST}}=7.4 \%\right)$ and weak yet significant IBD was noted at nSSRs (Online Resource 4), suggesting that the differentiation was rather drift-induced. As expected from the more variable cpSSRs that recruit from the non-recombining plastid genome, the among-population differentiation was high $\left(F_{\mathrm{ST}}=19.8 \%\right)$.

The genetic barriers among populations detected using nSSRs correspond roughly to the general division of the genetic diversity of Alpine biota into four groups encompassing the South-Western, Western, Central and Eastern Alps (Schmitt 2017). Less pronounced yet still noticeable was the division into two parts that agrees with the genetic division assuming the western and eastern domain (Thiel-Egenter et al. 2011; Mosca et al. 2014). Among three STRUCTURE clusters, weak geographically dependent structure was inferred. Specifically, the homogenization of the diversity among populations at the Western Alps was apparent in which a single cluster predominated (cluster II); only populations 1 and 3 from this group displayed considerable admixture from other gene pools (cluster I). Slightly more differentiation and admixing were visible in populations from the eastern part of the Alps. Cluster III prevailed in the most easterly located populations 11 and 12, possibly indicating a south-eastern or even eastern colonization route (Fig. 2). However, denser sampling in the Eastern Alps would be highly recommended to make clear inferences about eastern Alpine refugia and their contribution in recolonization.

\section{Possible peripheral LGM refugia for Salix serpillifolia}

Many high-alpine species show clear edaphic limitations that may determine the possibility of survival and the genetic structure (Alvarez et al. 2009). Siliceous substrate dominates mainly in the inner Alps, which were covered with ice sheets during the glaciation period (Kelly et al. 2004). Consequently, wider possibilities for refugial persistence are predicted for calcicolous plants such as S. serpillifolia, for which the widespread territories in the southern and northern outskirts of the Alps were likely available (Tribsch et al. 2002; Tribsch and Schönswetter 2003; Tribsch 2004). 
Fig. 4 MaxEnt-modelled geographic distributions under a current, and b Last Glacial Maximum climate conditions
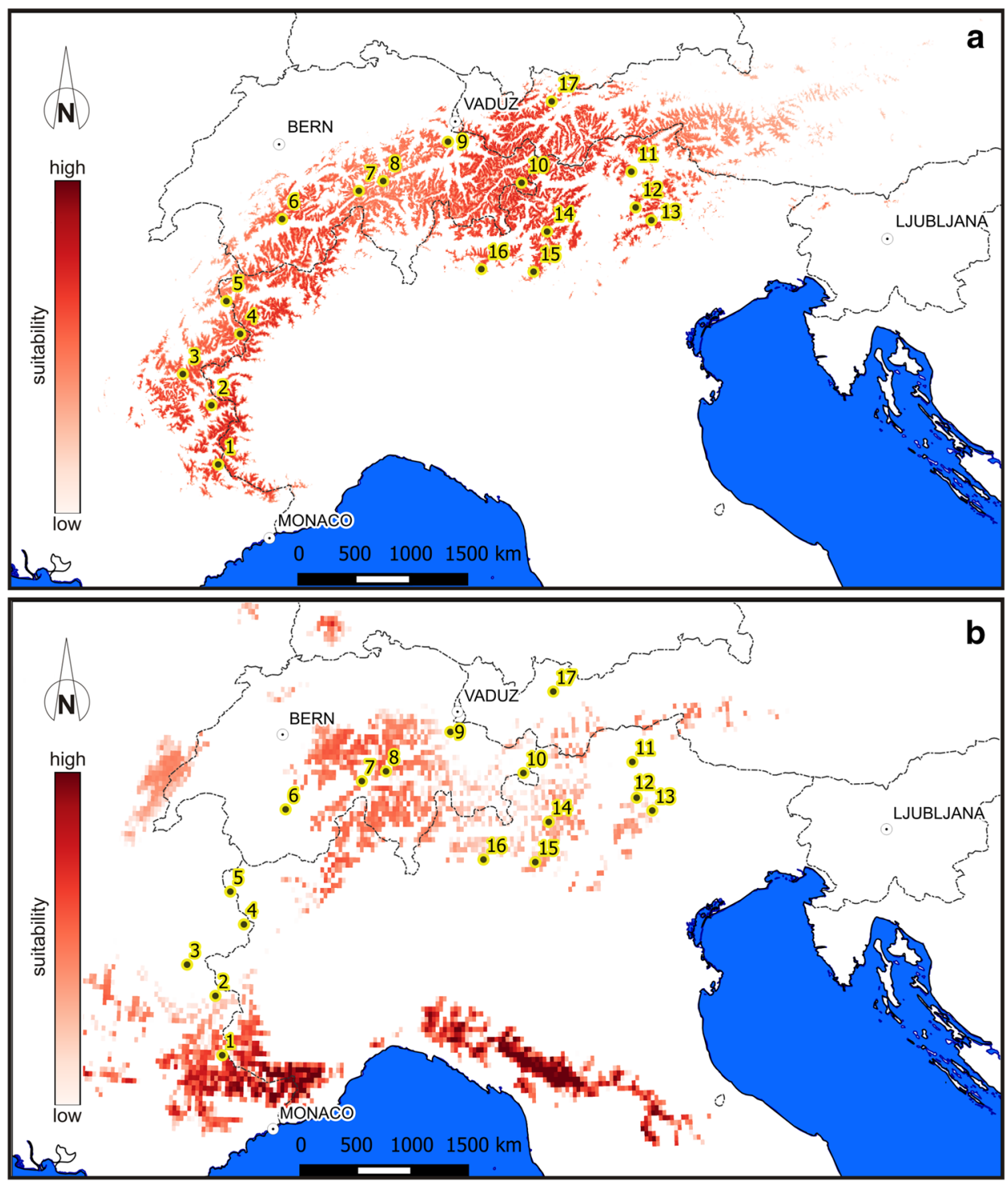

The south-western periphery of the Alps remained largely free of ice during the Pleistocene and was characterized by suitable calcareous habitats (Ehlers and Gibbard 2004; Naciri and Gaudeul 2007). This part of the Alps is frequently described as a refugial area for numerous herbaceous plant (e.g. Gaudeul et al. 2000; Stehlik et al. 2002b; Schönswetter et al. 2002; 2003a; 2004; Ehrich et al. 2007; Naciri and Gaudeul 2007; Paun et al. 2008; Rogivue et al. 2018). With considerable support, this part of the Alps was indicated by MaxEnt as the main area of $S$. serpillifolia occurrence during the LGM (Fig. 4b). Interestingly, MaxEnt indicated also more southerly located the Apuan Alps in the Northern Apennines as a potential area of the species survival of the glacial period, but there is no additional evidence in support of this possibility, therefore, the niche modelling can be here an artefact. Moreover, the applied model was based on bioclimatic variables without considering the other important factors affecting the distribution of species, such as substrate type or orographic complexity.

The genetic analysis also revealed a significant structure among the populations inhabiting the south-western part of the Alps, especially in the cpSSRs. The private haplotypes that were detected in our dataset were primarily concentrated in this area (Table 4). Specifically, population 1 located in the Maritime Alps was characterized with a distinct genetic makeup that was confirmed by both marker systems (nSSRs and cpSSRs), and this may be expected due to its long-term isolation. Low to moderate indicators of genetic diversity at the nSSRs and cpSSRs were noted in this population. A founder effect or long-term in situ persistence under isolation could result in the genetic impoverishment of population 1. However, which of those two processes was responsible for the reduction in genetic diversity cannot be fully explained with our genetic data. With regards to the other 
populations from this region, the location of populations 2 and 4 strictly overlap with the already outlined peripheral south-western refugium (Schönswetter et al. 2005), and their haplotypic composition further supports their genetic distinctiveness and thus likely refugial character.

Nuclear SSRs indicates that the LGM refugia for S. serpillifolia might have been located also in the southern part of the Eastern Alps. The genetic diversity was above average in most of the populations from this region that is one of the indicators of refugial status. Population 12 (the Dolomites), in particular, was characterized by the highest average number of alleles, private alleles and expected heterozygosity. This population, along with population 14 , belongs to the area of southern-alpine peripheral refugium between Lake Como and the Dolomites, where many other species probably survived during the LGM (e.g. Schönswetter et al. 2002, 2003a, 2004; Tribsch et al. 2002; Naciri and Gaudeul 2007). Interestingly, population 9 from the Glarus Alps refers to the eastern-alpine populations. It is located in the Western Alps (near the border with the Eastern Alps), but more northerly and closer to putative northern alpine peripheral refugia. This population was second in terms of genetic diversity. Nevertheless, regarding $S$. serpillifolia, there was not a distinct north-south split between populations 12 and 9. Conversely, their genetic distance and structure were rather close, suggesting considerable postglacial gene flow in this longitudinal direction.

Although the easternmost parts of the Alps remained largely unglaciated during the LGM (Ivy-Ochs et al. 2008), this area was not indicated by MaxEnt as a potential refugium for S. serpillifolia. Nevertheless, it is acknowledged to be an important glacial refugium for many high-mountain plants (e.g. Gugerli et al. 2009; Mosca et al. 2012; Ronikier et al. 2008; Stehlik et al. 2001; Schönswetter et al. 2002, a, b, 2004; Tribsch et al. 2002; Mráz et al. 2007). Considerable genetic distinctiveness of population 11 (the Sarntal Alps), which is the most easterly located population in our study, may suggest that this part of the Alps might have harboured populations of this species during the LGM. On the other hand, the detected bottleneck effect may also be responsible for the obtained pattern of differentiation. Unfortunately, we did not sample any population of $S$. serpillifolia in the eastern peripheries of the Alpine range, which does not allow us to draw a final conclusion on the role of this area as a potential glacial refugium for this species.

\section{Nunatak refugia for S. serpillifolia: yes or no?}

The central part of the Swiss Alps was indicated by MaxEnt as climatically suitable for $S$. serpillifolia during the LGM. This area corresponds to the locations of the nunatak refugia, which increases the overall likelihood of our hypothesis concerning $S$. serpillifolia survival on nunataks (Stehlik 2000; Schönswetter et al. 2005) (Fig. 4b).

The past species occurrence may be inferred directly from the in situ fossils. To the best of our knowledge, there are only three fossil records of $S$. retusa agg. dated back to the Late Glacial (14,600-12,000 years BP) (Fig. 1) (Gaillard and Moulin 1989; Tinner et al. 1996; Hadorn et al. 2002; Tinner and Kaltenrieder 2005; Drescher-Schneider et al. 2007; Leesch et al. 2012). The example of one of them, the Gouille Rion, which is situated at high elevation (2343 $\mathrm{m}$ a.s.1.) in the Swiss Central Alps, shows that $S$. retusa-type (including $S$. serpillifolia) willows might have appeared relatively quickly after the retreating of the ice sheet. This may be explained both by effective long-distance dispersal as well as by the sources of diaspores located nearby, i.e. nunatak survival. Nevertheless, these paleobotanical data originate from the late glacial period, and thus cannot directly confirm the nunatak survival of S. serpillifolia. Interestingly, the existence of nunatak refugia was recently suggested for several tree species (Carcaillet and Blarquez 2017, 2019; Carcaillet et al. 2018). The authors gave many examples to support the idea that the inner Alpine massifs (even above $2000 \mathrm{~m}$ a.s.l.) sheltered the glacial refugia for mountain and stone pines, larch and birch. Although this idea is inspiring and should be considered in our discussion, it still remains controversial and continues to be the subject of interesting debate (Finsinger et al. 2018).

Our results give an indication of possible nunatak survival of $S$. serpillifolia in populations from the inner part of the Alps, specifically from the central Swiss Alps, due to their location and the very distinct genetic characteristics demonstrated by cpSSRs (Fig. 3). Specifically, in our opinion, the best candidates for nunatak survival are monotypic populations 6 and 10 and the polytypic populations 7 and 8 ; the two latter show the combination of their exclusive clusters and an admixture from clusters occurring in the Western and Eastern Alps. Moreover, populations 6 and 10 are situated in the vicinity of potential nunatak refugial areas that were defined by Schönswetter et al. (2005), and population 7 is almost entirely composed of the private cpSSRs haplotypes. In this respect, population 5 in the western Alps, which is located at an elevation of $2100 \mathrm{~m}$, also shows distinct genetic characteristics and could, therefore, be included in the category of the nunatak refugia. According to the nunatak hypothesis, small and isolated populations might have built up their genetic distinctiveness by the accumulation of new mutations, bottlenecks, inbreeding, and random fluctuations in haplotype frequencies (genetic drift effect) that would eventually lead to loss or fixation of some haplotypes (Ellstrand and Elam 1993; Frankham 1996; Hewitt 2004; Mee and Moore 2014). The latter explanation would be exemplified by populations 5 and 7 , which both experienced bottlenecks 
that are likely responsible for their distinctiveness. Most of the populations that we suggest to be the nunatak survivors experienced demographic decline which is highly possible during harsh conditions of the LGM. Additionally, nunatak refugia need to be assumed to be rather spatially confined that also makes the occurrence of bottleneck more likely. Consequently, populations 5, 6, 7, 8 and 10 would outline the location of the nunatak refugia in the Alps that would extend those regions that were previously proposed by Schönswetter et al. (2005).

Chloroplast markers which are maternally inherited and efficiently dispersed by seeds, allow seed migration to be traced. However, the efficient dispersion of seeds may easily influence the original gene pool of the isolated populations by swamping their genetic distinctiveness. Willows are anemochoric, which is generally acknowledged to be an efficient mode of gene dispersal. Hence, three of the five populations designated here to be nunatak survivors $(5,7$, and 8), present admixture from surrounding stands during the postglacial period.

Salix serpillifolia can reproduce clonally. During sampling, we intended to avoid ramets but we found two identical multilocus genotypes in four populations, which were separated by at least $20 \mathrm{~m}$; this finding gives a very rough hint on the clonal spread of this species. It has been suggested, that this life history trait might have been crucial for forming refugia in northern latitudes (Bhagwat and Willis 2008; Dering et al. 2016; Westergaard et al. 2018) and would surely be so in the case of nunatak refugia. However, the increased prevalence of clonal spread may lead to the partial loss of genetic variability (Dering et al. 2016). Clonality may also result in the fixation of a few genotypes, due to its prevalence in size-confined refugial populations, giving them a distinct genetic composition.

\section{Conclusions}

Nunatak survival is still controversial topic in phylogeographic studies. In this work, we combined genetic structure analysis and species distribution modelling to verify the hypothesis on nunatak refugia for S. serpillifolia. We have found a certain genetic support for in situ glacial survival on Alpine nunataks in five populations from the inner part of the Swiss Alps. Nevertheless, this genetic signal is rather weak, since the genetic composition of the local refugial micropopulations was likely blurred by gene flow of periglacial genotypes during the Holocene.

Acknowledgements We would like to thank Dr. Andreas Hilpold (Institute for Alpine Environment, European Academy of Bozen/ Bolzano) and Dr. Konrad Pagitz (University of Innsbruck) for their help in material collection, and Prof. Jerzy Zieliński (Institute of Dendrology in Kórnik) for fruitful discussions and for sharing his knowledge on the systematics of the genus Salix.

Funding This study was financially supported by the Polish National Science Centre (NCN), project no. N N303 798240.

\section{Compliance with ethical standards}

Conflict of interest Data and findings presented in this manuscript have not been published and are not under consideration for publication elsewhere. All the authors have approved this submission and all persons entitled to authorship have been named. The authors have no conflict of interest to declare.

Declaration of authorship PK gave the idea, designed the research, and collected plant material; PK, MD, KS, ŁW conducted genetic and statistical analyses; PK, MD, KS, AB wrote the paper.

Open Access This article is distributed under the terms of the Creative Commons Attribution 4.0 International License (http://creativeco mmons.org/licenses/by/4.0/), which permits unrestricted use, distribution, and reproduction in any medium, provided you give appropriate credit to the original author(s) and the source, provide a link to the Creative Commons license, and indicate if changes were made.

\section{References}

Alvarez N, Thiel-Egenter C, Tribsch A et al (2009) History or ecology? Substrate type as a major driver of spatial genetic structure in alpine plants. Ecol Lett 12:632-640. https://doi.org/10.111 1/j.1461-0248.2009.01312.x

Asse D, Chuine I, Vitasse Y et al (2018) Warmer winters reduce the advance of tree spring phenology induced by warmer springs in the Alps. Agric For Meteorol 252:220-230. https://doi. org/10.1016/j.agrformet.2018.01.030

Barker JHA, Pahlich A, Trybush S et al (2003) Microsatellite markers for diverse Salix species. Mol Ecol Notes 3:4-6. https://doi.org/ 10.1046/j.1471-8286.2003.00332.x

Bennett KD, Tzedakis PC, Willis KJ (1991) Quaternary refugia of North European trees. J Biogeogr 18:103-115. https://doi. org/10.2307/2845248

Bhagwat SA, Willis KJ (2008) Species persistence in northerly glacial refugia of Europe: a matter of chance or biogeographical traits? J Biogeogr 35:464-482. https://doi.org/10.111 1/j.1365-2699.2007.01861.x

Birks HH (2008) The late-quaternary history of arctic and alpine plants. Plant Ecol Divers 1:135-146. https://doi.org/10.1080/17550 870802328652

Carcaillet C, Blarquez O (2017) Fire ecology of a tree glacial refugium on a nunatak with a view on alpine glaciers. New Phytol 216:1281-1290. https://doi.org/10.1111/nph.14721

Carcaillet C, Blarquez O (2019) Glacial refugia in the south-western Alps? New Phytol 222:663-667. https://doi.org/10.1111/ nph. 15673

Carcaillet C, Latil J-L, Abou S et al (2018) Keep your feet warm? A cryptic refugium of trees linked to a geothermal spring in an ocean of glaciers. Glob Change Biol 24:2476-2487. https://doi. org/10.1111/gcb.14067

Carvalho DD, Ingvarsson PK, Joseph J et al (2010) Admixture facilitates adaptation from standing variation in the European 
aspen (Populus tremula L.), a widespread forest tree. Mol Ecol 19:1638-1650. https://doi.org/10.1111/j.1365-294X.2010.04595 . $\mathrm{X}$

Chapuis M-P, Estoup A (2007) Microsatellite null alleles and estimation of population differentiation. Mol Biol Evol 24:621-631. https://doi.org/10.1093/molbev/msl191

Chybicki IJ, Burczyk J (2009) Simultaneous estimation of null alleles and inbreeding coefficients. J Hered 100:106-113. https://doi. org/10.1093/jhered/esn088

Collins WD, Bitz CM, Blackmon ML et al (2006) The community climate system model version 3 (CCSM3). J Clim 19:2122-2143. https://doi.org/10.1175/JCLI3761.1

Comes HP, Kadereit JW (1998) The effect of quaternary climatic changes on plant distribution and evolution. Trends Plant Sci 3:432-438

Corander J, Sirén J, Arjas E (2008) Bayesian spatial modeling of genetic population structure. Comput Stat 23:111-129. https:// doi.org/10.1007/s00180-007-0072-x

Dering M, Latałowa M, Boratyńska K et al (2016) Could clonality contribute to the northern survival of grey alder [Alnus incana (L.) Moench] during the last glacial maximum? Acta Soc Bot Pol. https://doi.org/10.5586/asbp.3523

Dostál J (1989) Nová květena ČSSR. I. Academia, Prague

Doyle JJ, Doyle JL (1987) A rapid DNA isolation procedure for small quantities of fresh leaf tissue. Phytochem Bull 19:11-15

Drescher-Schneider R, de Beaulieu J-L, Magny M et al (2007) Vegetation history, climate and human impact over the last 15,000 years at Lago dell'Accesa (Tuscany, Central Italy). Veg Hist Archaeobot 16:279-299. https://doi.org/10.1007/s00334-006-0089-z

Ehlers J, Gibbard PL (2004) Quaternary glaciations-extent and chronology: part I: Europe. Elsevier, New York

Ehrich D, Gaudeul M, Assefa A et al (2007) Genetic consequences of Pleistocene range shifts: contrast between the Arctic, the Alps and the East African mountains. Mol Ecol 16:2542-2559. https ://doi.org/10.1111/j.1365-294X.2007.03299.x

Eliades N-G, Eliades DG (2009) HAPLOTYPE ANALYSIS: software for analysis of haplotype data. Forest Genetics and Forest Tree Breeding, Georg-August University Goettingen, Germany. http:// www.uni-goettingen.de/en/134935.html. Accessed 25 May 2018

Elith J, Phillips SJ, Hastie T et al (2011) A statistical explanation of MaxEnt for ecologists. Divers Distrib 17:43-57. https://doi.org/ $10.1111 / \mathrm{j} .1472-4642.2010 .00725 . \mathrm{x}$

Ellenberg HH (1988) Vegetation ecology of Central Europe. Cambridge University Press, Cambridge

Ellstrand NC, Elam DR (1993) Population genetic consequences of small population size: implications for plant conservation. Annu Rev Ecol Syst 24:217-242. https://doi.org/10.1146/annur ev.es.24.110193.001245

Evanno G, Regnaut S, Goudet J (2005) Detecting the number of clusters of individuals using the software structure: a simulation study. Mol Ecol 14:2611-2620. https://doi.org/10.1111/j.1365294X.2005.02553.x

Favarger C (1972) Endemism in the montane floras of Europe. In: Valentine DH (ed) Taxonomy, phytogeography and evolution. Academic Press, London, pp 191-204

Felsenstein J (1989) Mathematics vs. evolution. Science 246:941-942. https://doi.org/10.1126/science.246.4932.941

Finkeldey R, Murillo O (1999) Contributions of subpopulations to total gene diversity. Theor Appl Genet 98:664-668. https://doi. org/10.1007/s001220051118

Finsinger W, Schwörer C, Heiri O et al (2018) Fire on ice and frozen trees? Inappropriate radiocarbon dating leads to unrealistic reconstructions. New Phytol. https://doi.org/10.1111/nph.15354

Frankham R (1996) Relationship of genetic variation to population size in wildlife. Conserv Biol 10:1500-1508. https://doi.org/10.104 6/j.1523-1739.1996.10061500.x
Gabrielsen TM, Bachmann K, Jakobsen KS, Brochmann C (1997) Glacial survival does not matter: RAPD phylogeography of Nordic Saxifraga oppositifolia. Mol Ecol 6:831-842. https://doi. org/10.1046/j.1365-294X.1997.d01-215.x

Gaillard M-J, Moulin B (1989) New results on the Lateglacial history and environment of the lake of Neuchâtel (Switzerland). Sedimentological and palynological investigations at the palaeolithic site of Hauterive-Champréveyres. Eclogae Geologicae Helvetiae 82:203-218

Garza JC, Williamson EG (2001) Detection of reduction in population size using data from microsatellite loci. Mol Ecol 10:305318. https://doi.org/10.1046/j.1365-294X.2001.01190.x

Gaudeul M, Taberlet P, Till-Bottraud I (2000) Genetic diversity in an endangered alpine plant, Eryngium alpinum L. (Apiaceae), inferred from amplified fragment length polymorphism markers. Mol Ecol 9:1625-1637. https://doi.org/10.1046/j.1365294x.2000.01063.x

Gavin DG, Fitzpatrick MC, Gugger PF et al (2014) Climate refugia: joint inference from fossil records, species distribution models and phylogeography. New Phytol 204:37-54. https://doi. org/10.1111/nph.12929

Goldstein DB, Linares AR, Cavalli-Sforza LL, Feldman MW (1995) An evaluation of genetic distances for use with microsatellite loci. Genetics 139:463-471

Goudet J (1995) FSTAT (Version 1.2): a computer program to calculate F-statistics. J Hered 86:485-486

Goudet J (2003) FSTAT (ver. 2.9.4), a program to estimate and test population genetics parameters. https://www2.unil.ch/popgen/ softwares/fstat.htm. Accessed 20 Feb 2019

Grichuk VP (1992) Main types of vegetation (ecosystems) during the maximum cooling of the last glaciations. In: Frenzel B, Pécsi M, Velichko AA (eds) Atlas of paleoclimates and paleoenvironments of the Northern Hemisphere: late Pleistocene - Holocene. Geographical Research Institute, Hungarian Academy of Sciences, Budapest; Gustav Fischer Verlag, Stuttgart, pp 57 (map), 123124 (explanatory note)

Gugerli F, Rüegg M, Vendramin GG (2009) Gradual decline in genetic diversity in Swiss stone pine populations (Pinus cembra) across Switzerland suggests postglacial re-colonization into the Alps from a common eastern glacial refugium. Bot Helv 119:13. https://doi.org/10.1007/s00035-009-0052-6

Hadorn P, Thew N, Coope RG et al (2002) A late-glacial and early holocene environment and climate history for the Neuchâtel region $(\mathrm{CH})$. In: Richard H, Vignot A (eds) Équilibres et ruptures dans les ecosystemes depuis 20000 ans en Europe de l'Ouest. Presses Universitaires de Franche-Comté, Besançon, pp 75-90

Hewitt GM (2004) Genetic consequences of climatic oscillations in the quaternary. Philos Trans R Soc Lond B Biol Sci 359:183-195. https://doi.org/10.1098/rstb.2003.1388

Hijmans RJ, Cameron SE, Parra JL et al (2005) Very high resolution interpolated climate surfaces for global land areas. Int J Climatol 25:1965-1978. https://doi.org/10.1002/joc.1276

Hörandl E, Florineth F, Hadacek F (2002) Weiden in Österreich und angrenzenden Gebieten. Eigenverlag des Arbeitsbereiches Ingenieurbiologie und Landschaftsbau. Institut für Landschaftsplanung und Ingenieurbiologie, Universität für Bodenkultur, Wien

Huntley B, Birks H (1983) An atlas of past and present pollen maps for Europe, 0-13,000 years ago. Cambridge University Press, Cambridge

Idury RM, Cardon LR (1997) A simple method for automated allele binning in microsatellite markers. Genome Res 7:1104-1109. https://doi.org/10.1101/gr.7.11.1104

Ivy-Ochs S, Kerschner H, Reuther A et al (2008) Chronology of the last glacial cycle in the European Alps. J Quat Sci 23:559-573. https://doi.org/10.1002/jqs.1202 
Kelly MA, Buoncristiani J-F, Schlüchter C (2004) A reconstruction of the last glacial maximum (LGM) ice-surface geometry in the western Swiss Alps and contiguous Alpine regions in Italy and France. Eclogae Geologicae Helvetiae 97:57-75. https://doi. org/10.1007/s00015-004-1109-6

Koblížek J (2006) Salix L. In: Goliašová K, Michalková E (eds) Flóra Slovenska. Veda, Bratislava, pp 209-290

Kopelman NM, Mayzel J, Jakobsson M et al (2015) Clumpak: a program for identifying clustering modes and packaging population structure inferences across K. Mol Ecol Resour 15:1179-1191. https://doi.org/10.1111/1755-0998.12387

Kosiński P, Boratyński A, Hilpold A (2017) Taxonomic differentiation of Salix retusa agg. (Salicaceae) based on leaf characteristics. Dendrobiology 78:40-50. https://doi.org/10.12657/denbi 0.078 .005

Kosiński P, Sliwinska E, Hilpold A, Boratyński A (2019) DNA ploidy in Salix retusa agg. only partly in line with its morphology and taxonomy. Nord J Bot 37(7):1-8. https://doi.org/10.1111/ njb.02197

Lang G (1994) Quartäre Vegetationsgeschichte Europas: Methoden und Ergebnisse. G. Fischer, Schaffhausen

Leesch D, Müller W, Nielsen E, Bullinger J (2012) The Magdalenian in Switzerland: re-colonization of a newly accessible landscape. Quat Int 272-273:191-208. https://doi.org/10.1016/j.quain t.2012.04.010

Lian C, Oishi R, Miyashita N et al (2003) Genetic structure and reproduction dynamics of Salix reinii during primary succession on Mount Fuji, as revealed by nuclear and chloroplast microsatellite analysis. Mol Ecol 12:609-618. https://doi.org/10.1046/j.1365294X.2003.01756.x

Manni F, Guérard E, Heyer E (2004) Geographic patterns of (genetic, morphologic, linguistic) variation: how barriers can be detected by using Monmonier's algorithm. Hum Biol 76:173-190

Mee JA, Moore J-S (2014) The ecological and evolutionary implications of microrefugia. J Biogeogr 41:837-841. https://doi. org/10.1111/jbi.12254

Mosca E, Eckert AJ, Di Pierro EA et al (2012) The geographical and environmental determinants of genetic diversity for four alpine conifers of the European Alps. Mol Ecol 21:5530-5545. https:// doi.org/10.1111/mec.12043

Mosca E, González-Martínez SC, Neale DB (2014) Environmental versus geographical determinants of genetic structure in two subalpine conifers. New Phytol 201(1):180-192. https://doi. org/10.1111/nph.12476

Mráz P, Gaudeul M, Rioux D et al (2007) Genetic structure of Hypochaeris uniflora (Asteraceae) suggests vicariance in the Carpathians and rapid post-glacial colonization of the Alps from an eastern Alpine refugium. J Biogeogr 34:2100-2114. https:// doi.org/10.1111/j.1365-2699.2007.01765.x

Naciri Y, Gaudeul M (2007) Phylogeography of the endangered Eryngium alpinum L. (Apiaceae) in the European Alps. Mol Ecol 16:2721-2733. https://doi.org/10.1111/j.1365-294X.2007.03269 . $\mathrm{X}$

Nève G, Verlaque R (2010) Genetic differentiation between and among refugia. In: Habel JC, Assmann T (eds) Relict species. Phylogeography and conservation biology. Springer, Berlin, pp 277-294

Paun O, Schönswetter P, Winkler M, Tribsch A (2008) Historical divergence versus contemporary gene flow: evolutionary history of the calcicole Ranunculus alpestris group (Ranunculaceae) in the European Alps and the Carpathians. Mol Ecol 17:4263-4275

Peakall R, Smouse PE (2012) GenAlEx 6.5: genetic analysis in Excel. Population genetic software for teaching and research-an update. Bioinformatics 28:2537-2539. https://doi.org/10.1093/ bioinformatics/bts460

Peery MZ, Kirby R, Reid BN et al (2012) Reliability of genetic bottleneck tests for detecting recent population declines. Mol Ecol
21:3403-3418. https://doi.org/10.1111/j.1365-294X.2012.05635

Phillips SJ, Dudík M, Schapire RE (2004) A maximum entropy approach to species distribution modeling. In: Proceedings of the twenty-first international conference on machine learning, pp 655-662. https://doi.org/10.1145/1015330.1015412

Pritchard JK, Stephens M, Donnelly P (2000) Inference of population structure using multilocus genotype data. Genetics 155:945-959

Rangwala I, Miller JR (2012) Climate change in mountains: a review of elevation-dependent warming and its possible causes. Clim Change 114:527-547. https://doi.org/10.1007/s1058 4-012-0419-3

Ravazzi C (2002) Late quaternary history of spruce in southern Europe. Rev Palaeobot Palynol 120:131-177. https://doi.org/10.1016/ S0034-6667(01)00149-X

Raymond M, Rousset F (1995) GENEPOP (version 1.2): population genetics software for exact tests and ecumenicism. J Hered 86:248-249. https://doi.org/10.1093/oxfordjournals.jhered.a1115 73

Rechinger KH (1957) Salix L. Illustrierte flora von Mitteleuropa, 2nd edn. C. Hanser, Munich, pp 44-135

Rechinger KH (1992) Salix taxonomy in Europe-problems, interpretations, observations. Proc R Soc Edinb Sect B Biol Sci 98:1-12. https://doi.org/10.1017/S0269727000007417

Rogivue A, Graf R, Parisod C et al (2018) The phylogeographic structure of Arabis alpina in the Alps shows consistent patterns across different types of molecular markers and geographic scales. Alp Bot 128:35-45. https://doi.org/10.1007/s00035-017-0196-8

Ronikier M, Cieślak E, Korbecka G (2008) High genetic differentiation in the alpine plant Campanula alpina Jacq. (Campanulaceae): evidence for glacial survival in several Carpathian regions and long-term isolation between the Carpathians and the Alps. Mol Ecol 17:1763-1775. https://doi.org/10.1111/j.1365294X.2008.03664.X

Schmitt T (2017) Molecular biogeography of the high mountain systems of Europe: an overview. In: Catalan J, Ninot J, Aniz M (eds) High mountain conservation in a changing world. Springer, Cham, pp 63-74

Schneeweiss GM, Schönswetter P (2010) The wide but disjunct range of the European mountain plant Androsace lactea L. (Primulaceae) reflects Late Pleistocene range fragmentation and postglacial distributional stasis. J Biogeogr 37:2016-2025. https:// doi.org/10.1111/j.1365-2699.2010.02350.x

Schneeweiss GM, Schönswetter P (2011) A re-appraisal of nunatak survival in arctic-alpine phylogeography. Mol Ecol 20:190-192. https://doi.org/10.1111/j.1365-294X.2010.04927.x

Schönswetter P, Schneeweiss GM (2019) Is the incidence of survival in interior Pleistocene refugia (nunataks) underestimated? Phylogeography of the high mountain plant Androsace alpina (Primulaceae) in the European Alps revisited. Ecol Evol 9:4078-4086. https://doi.org/10.1002/ece3.5037

Schönswetter P, Tribsch A, Barfuss M, Niklfeld H (2002) Several Pleistocene refugia detected in the high alpine plant Phyteuma globulariifolium Sternb. \& Hoppe (Campanulaceae) in the European Alps. Mol Ecol 11:2637-2647. https://doi.org/10.1046/j.1365294X.2002.01651.x

Schönswetter P, Tribsch A, Niklfeld H (2003a) Phylogeography of the high alpine cushion plant Androsace alpina (Primulaceae) in the European Alps. Plant Biol 5:623-630. https://doi. org/10.1055/s-2003-44686

Schönswetter P, Tribsch A, Schneeweiss GM, Niklfeld H (2003b) Disjunctions in relict alpine plants: phylogeography of Androsace brevis and A. wulfeniana (Primulaceae). Bot J Linn Soc 141:437446. https://doi.org/10.1046/j.0024-4074.2002.00134.x

Schönswetter P, Tribsch A, Stehlik I, Niklfeld H (2004) Glacial history of high alpine Ranunculus glacialis (Ranunculaceae) 
in the European Alps in a comparative phylogeographical context. Biol J Linn Soc 81:183-195. https://doi.org/10.111 1/j.1095-8312.2003.00289.x

Schönswetter P, Stehlik I, Holderegger R, Tribsch A (2005) Molecular evidence for glacial refugia of mountain plants in the European Alps. Mol Ecol 14:3547-3555. https://doi.org/10.1111/j.1365294X.2005.02683.x

Schönswetter P, Solstad H, García PE, Elven R (2009) A combined molecular and morphological approach to the taxonomically intricate European mountain plant Papaver alpinum s.l. (Papaveraceae) - taxa or informal phylogeographical groups? Taxon 58(4):1326-1343. https://doi.org/10.1002/tax.584020

Skrede I, Eidesen P, Portela R, Brochmann C (2006) Refugia, differentiation and postglacial migration in arctic-alpine Eurasia, exemplified by the mountain avens (Dryas octopetala L.). Mol Ecol 15:1827-1840. https://doi.org/10.1111/j.1365-294X.2006.02908 $\mathrm{x}$

Skvortsov AK (1999) Willows of Russia and adjacent countries. Taxonomical and geographical revision (English translation with additions). Joensuu University Press, Joensuu

Slatkin M (1995) A measure of population subdivision based on microsatellite allele frequencies. Genetics 139:457-462

Stamati K, Blackie S, Brown JWS, Russell J (2003) A set of polymorphic SSR loci for subarctic willow (Salix lanata, S. lapponum and S. herbacea). Mol Ecol Notes 3:280-282. https://doi.org/10 $.1046 / j .1471-8286.2003 .00426 . x$

Stamati K, Hollingsworth PM, Russell J (2007) Patterns of clonal diversity in three species of sub-arctic willow (Salix lanata, $S$. lapponum and S. herbacea). Plant Syst Evol 269:75-88. https:// doi.org/10.1007/s00606-007-0578-2

Stehlik I (2000) Nunataks and peripheral refugia for alpine plants during quaternary glaciation in the middle part of the Alps. Bot Helv 110:25-30

Stehlik I (2002) Glacial history of the alpine herb Rumex nivalis (Polygonaceae): a comparison of common phylogeographic methods with nested clade analysis. Am J Bot 89:2007-2016. https://doi.org/10.3732/ajb.89.12.2007

Stehlik I, Schneller JJ, Bachmann K (2001) Resistance or emigration: response of the high-alpine plant Eritrichium nanum (L.) Gaudin to the ice age within the Central Alps. Mol Ecol 10:357-370. https://doi.org/10.1046/j.1365-294X.2001.01179.x

Stehlik I, Blattner FR, Holderegger R, Bachmann K (2002a) Nunatak survival of the high alpine plant Eritrichium nanum (L.) Gaudin in the central Alps during the ice ages. Mol Ecol 11:2027-2036. https://doi.org/10.1046/j.1365-294X.2002.01595.x

Stehlik I, Schneller JJ, Bachmann K (2002b) Immigration and in situ glacial survival of the low-alpine Erinus alpinus (Scrophulariaceae). Biol J Linn Soc 77:87-103. https://doi.org/10.104 6/j.1095-8312.2002.00094.x

Steinbauer MJ, Grytnes J-A, Jurasinski G et al (2018) Accelerated increase in plant species richness on mountain summits is linked to warming. Nature 556:231. https://doi.org/10.1038/s4158 6-018-0005-6
Stewart JR, Lister AM, Barnes I, Dalén L (2010) Refugia revisited: individualistic responses of species in space and time. Proc $\mathrm{R}$ Soc Lond B Biol Sci 277:661-671. https://doi.org/10.1098/ rspb.2009.1272

Thiel-Egenter C, Alvarez N, Holderegger R et al (2011) Break zones in the distributions of alleles and species in alpine plants. J Biogeogr 38:772-782. https://doi.org/10.1111/j.1365-2699.2010.02441.x

Tinner W, Kaltenrieder P (2005) Rapid responses of high-mountain vegetation to early holocene environmental changes in the Swiss Alps. J Ecol 93:936-947. https://doi.org/10.111 1/j.1365-2745.2005.01023.x

Tinner W, Ammann B, Germann P (1996) Treeline fluctuations recorded for 12,500 years by soil profiles, pollen, and plant macrofossils in the Central Swiss Alps. Arct Alp Res 28:131-147. https://doi.org/10.2307/1551753

Tribsch A (2004) Areas of endemism of vascular plants in the Eastern Alps in relation to Pleistocene glaciation. J Biogeogr 31:747760. https://doi.org/10.1111/j.1365-2699.2004.01065.x

Tribsch A, Schönswetter P (2003) Patterns of endemism and comparative phylogeography confirm palaeoenvironmental evidence for Pleistocene refugia in the Eastern Alps. Taxon 52:477. https:// doi.org/10.2307/3647447

Tribsch A, Schönswetter P, Stuessy TF (2002) Saponaria pumila (Caryophyllaceae) and the ice age in the European Alps. Am J Bot 89:2024-2033. https://doi.org/10.3732/ajb.89.12.2024

Tuskan GA, Gunter LE, Yang ZK et al (2004) Characterization of microsatellites revealed by genomic sequencing of Populus trichocarpa. Can J For Res 34:85-93. https://doi.org/10.1139/ x03-283

Tzedakis PC, Emerson BC, Hewitt GM (2013) Cryptic or mystic? Glacial tree refugia in northern Europe. Trends Ecol Evol 28:696704. https://doi.org/10.1016/j.tree.2013.09.001

Westergaard KB, Zemp N, Bruederle LP et al (2018) Population genomic evidence for plant glacial survival in Scandinavia. Mol Ecol. https://doi.org/10.1111/mec.14994

Wiens JJ, Graham CH (2005) Niche conservatism: integrating evolution, ecology, and conservation biology. Annu Rev Ecol Evol Syst 36:519-539. https://doi.org/10.1146/annurev.ecols ys.36.102803.095431

Williamson-Natesan EG (2005) Comparison of methods for detecting bottlenecks from microsatellite loci. Conserv Genet 6:551-562. https://doi.org/10.1007/s10592-005-9009-5

Wright S (1931) Evolution in Mendelian Populations. Genetics 16:97-159

Zeng Y-F, Zhang J-G, Duan A-G, Abuduhamiti B (2016) Genetic structure of Populus hybrid zone along the Irtysh River provides insight into plastid-nuclear incompatibility. Sci Rep. https://doi. org/10.1038/srep28043

Publisher's Note Springer Nature remains neutral with regard to jurisdictional claims in published maps and institutional affiliations. 